\title{
KETAHANAN PANGAN RUMAH TANGGA PETANI PENGHASIL BERAS ORGANIK
}

\author{
(Household Food Security of Farmers who Yielding Organic Rice) \\ Anang Suhardianto ${ }^{1}$, Yayuk Farida Baliwati ${ }^{2}$, dan Dadang Sukandar ${ }^{2}$ \\ ${ }^{1}$ Alumni Program Studi Gizi Masyarakat dan Sumberdaya Keluarga, Sekolah Pascasarjana IPB \\ 2 Staf Pengajar Departemen Gizi Masyarakat, Fakultas Ekologi Manusia (FEMA) IPB \\ Telp: 0251-8628304/8621258; Fax: 0251-8625846/8622276
}

\begin{abstract}
ABST RACT
The study was designed to analyze level of household food security of farmers who plant organic rice and identify landholding that supporting household food security. For that purposes, 61 samples of household were selected from farming households in Ciburuy Village, Bogor Regency. Data collected was landholding, working capital, cooperation, education, purposes of practicing on organic farming, waste management, knowledge of organic farming, organic rice productivity, income, food consumption and level of household food security. Food recall $1 \times 24$ hours and food frequency (weekly, monthly, and yearly) were used to obtain food consumption data. Household food security was determined based on level of energy consumption. Landholding that supporting household food security was determined based on rice consumption and household productivity. The analyses results of household food security showed that $85.2 \%$ of households were secure and $14.8 \%$ were insecure. Variables that significantly influenced household food security were income, knowledge of organic farming, organic rice productivity, purposes of practicing on organic farming, landholding, and waste management. Pearson correlation analyses showed that income, knowledge of organic farming, organic rice productivity, and landholding had significant effect toward household food security. Spearman correlation analyses showed that purposes of practicing on organic farming and waste management had significant association with household food security too. Based on daily average of energy sufficiency, land-man ratio should be $318 \mathrm{~m}^{2} /$ person.
\end{abstract}

Keywords: household food security, organic farming, land-man ratio

\section{PENDAHULUAN}

\section{Latar Belakang}

Pertambahan penduduk yang melaju cepat menuntut ketersediaan pangan dalam jumlah yang cukup, mutu yang memadai, dan cepat pula. Tuntutan ini mendorong munculnya sistem pertanian modern yang memiliki ciriciri ketergantungan yang tinggi pada: (1) pupuk sintetis; (2) bahan kimia sintetis untuk pengendalian hama, penyakit, dan gulma; dan (3) varietas unggul untuk tanaman monokultur. Sistem pertanian modern memang terbukti ampuh dalam menjawab tantangan tersebut. Menurut Sutanto (2002), penggunaan pupuk sintetis dapat meningkatkan hasil pangan 50 hingga 60 persen. Namun, penggunaan bahan kimia sintetis yang intensif bukan tanpa risiko. Allen dan Dusen (1988) mengemukakan bahwa pertanian modern ini telah menyebabkan kemerosotan sifat-sifat tanah, percepatan erosi tanah, penurunan kualitas tanah, dan kontaminasi air bawah tanah. Hal ini menunjukkan bahwa tuntutan untuk meningkatkan produksi pertanian ternyata memiliki keterbatasan. Reijntjes et al. (1992) mengemukakan bahwa produktivitas ekosistem memiliki batas maksimal. Jika batas ini dilampaui, ekosistem akan mengalami degradasi bahkan kemungkinan akan runtuh sehingga hanya sedikit orang yang bisa bertahan hidup dengan sumberdaya yang tersisa. Menyadari hal tersebut, negara-negara industri membuat terobosan dengan memperkenalkan sistem pertanian berkelanjutan, salah satunya adalah pertanian organik.

Menurut FAO (2002), pertanian organik didefinisikan sebagai sistem manajemen produksi holistik yang meningkatkan dan mengembangkan kesehatan ekosistem, termasuk siklus biologi dan aktivitas biologi tanah. Dengan demikian, keuntungannya adalah terjaganya kondisi lingkungan dan terjaminnya keberlanjutan usahatani. Dari segi keamanan pangan, produk organik tidak menggunakan bahan pembasmi sintetis untuk hama dan penyakit, sehingga manusia terbebas dari dampak negatif akumu- 
lasi residu bahan sintetis tersebut dalam tubuhnya. Ditinjau dari sisi ketahanan pangan, petani menjadi memiliki peluang untuk memperbaiki aksesnya terhadap pangan.

Menurut perhitungan Andoko (2004), biaya operasional pembudidayaan padi secara organik hanya sebesar $72 \%$ dibandingkan dengan non organik. Selain itu, FAO (2002) juga melaporkan bahwa melalui proyek Jajarkot Permeaculture Programme di Nepal, pertanian organik yang diterapkan pada lahan seluas 350 ha menunjukkan peningkatan hasil panen padi dari 1.8 menjadi 2.4 ton/ha dan jagung dari 1.2 menjadi 1.6 ton/ha. Dengan biaya produksi yang menurun dan hasil yang cenderung meningkat maka petani organik memiliki peluang untuk meningkatkan pendapatannya sehingga akses petani terhadap pangan juga meningkat. Akses rumah tangga terhadap pangan merupakan dimensi terpenting dari ketahanan pangan rumah tangga (Maxwell \& Frankenberger, 1992). Namun demikian permasalahannya adalah penguasaan lahan oleh petani tidak memadai. Rumah tangga petani di Kabupaten Bogor hanya menguasai lahan rata-rata 0.34 ha (BPS, 2004). Masalah lain adalah tingginya balita penyandang gizi buruk di Kabupaten Bogor. Telah terjadi peningkatan balita penyandang gizi buruk sebesar $79.1 \%$, yaitu dari 3313 balita pada tahun 2005 menjadi 5934 balita pada tahun 2006. Sedangkan balita penyandang gizi kurang pada 2006 telah mencapai 10000 balita (BKKBN, 2006).

\section{$\underline{\text { Tujuan }}$}

Penelitian ini bertujuan untuk mempelajari katahanan pangan rumah tangga petani penghasil beras organik. Secara khusus, penelitian ini bertujuan untuk: (1) Menganalisis tingkat ketahanan pangan rumah tangga petani penghasil beras organik; dan (2) Mengidentifikasi penguasaan lahan dalam mendukung ketahanan pangan rumah tangga.

\section{METODE PENELITIAN}

\section{Desain, Tempat dan Waktu Penelitian}

Penelitian ini menggunakan desain Cross Sectional. Tempat penelitian adalah di Desa Ciburuy, Kecamatan Cigombong, Kabupaten Bogor. Tempat penelitian sengaja dipilih dengan pertimbangan kekhususan dari jenis usaha tani penghasil beras organik dan lamanya menerapkan sistem pertanian organik. Petani di tempat penelitian telah menerapkan pertanian organik minimal 3 (tiga) tahun. Menurut
SNI (2002), untuk dapat menerapkan prinsipprinsip produksi pangan organik, lahan harus telah mengalami masa konversi dari pertanian konvensional ke pertanian organik paling sedikit 2 (dua) tahun sebelum penebaran benih. Penelitian ini dilakukan mulai Mei sampai dengan Agustus 2006.

\section{Prosedur Penarikan Contoh}

Populasi dalam penelitian ini adalah rumahtangga peserta Program Pemberdayaan Petani Sehat yang diselenggarakan oleh Lembaga Pertanian Sehat bekerjasama dengan Gabungan Kelompok Tani Silih Asih di Desa Ciburuy, Kecamatan Cigombong, Kabupaten Bogor. Sampel dipilih secara acak dengan ukuran sebesar 61 rumah tangga dengan pertimbangan agar nilai-nilai yang diperoleh berdistribusi normal. Menurut Mantra dan Kasto (1989), sampel yang tergolong sampel besar yang distribusinya normal adalah sampel yang jumlahnya > 30 kasus, yang diambil secara acak (random).

Data yang dikumpulkan meliputi data primer dan sekunder. Data primer meliputi peubah: penguasaan lahan, modal kerja, kerjasama, pendidikan formal dan non formal kepala keluarga, tujuan penerapan pertanian organik, pengelolaan limbah, pengetahuan untuk bertani organik, produksi beras organik, pendapatan rumah tangga, dan tingkat konsumsi pangan rumah tangga. Pengumpulan data primer diperoleh melalui wawancara langsung dengan responden yang berpedoman pada kuesioner yang telah dipersiapkan sebelumnya dan telah diujicobakan. Data konsumsi pangan dilakukan dengan cara recall konsumsi pangan $1 \times 24$ jam, dan food frequency (seminggu, sebulan, dan setahun). Data sekunder yang dikumpulkan meliputi monografi desa dan kecamatan, curah hujan, zona agroklimat dan data-data lain yang menunjang penelitian. Datadata tersebut diperoleh dari Kantor Desa Ciburuy, Kantor Kecamatan Cigombong, Dinas Pertanian Kehutanan Kabupaten Bogor, dan Badan Pusat Statistik Kabupaten Bogor. Untuk lebih mendalami aspek-aspek kualitatif dari masalah dan tujuan penelitian, dilakukan penggalian informasi melalui wawancara secara mendalam terhadap tokoh masyarakat, aparat desa, serta petugas lapangan dari instansi terkait. Penggalian informasi juga dilakukan dengan pengamatan langsung di lapangan.

Indikator yang digunakan untuk mengukur ketahanan pangan rumah tangga adalah tingkat kecukupan konsumsi energi (TKE). 
Suatu rumah tangga disebut tahan pangan jika tingkat kecukupan energi $\geq 70 \%$, dan jika $<70 \%$ disebut tidak tahan pangan.

$$
\mathrm{TKE}=\frac{\text { Konsumsi Energi }}{\text { Kecukupan Energi }} \times 100 \%
$$

\section{Pengolahan dan Analisis Data}

Data yang diperoleh diolah dan dianalisis menggunakan perangkat lunak komputer SPSS 11.5 for Windows dan SAS 9 for Windows. Untuk melihat hubungan antar variabel digunakan analisis korelasi dan untuk menentukan faktorfaktor determinan dari variabel-variabel bebas yang mempengaruhi ketahanan pangan digunadigunakan analisis regresi linear berganda. Persamaan umum yang digunakan adalah sebagai berikut:

$$
\begin{aligned}
Y= & \beta_{0}+\beta_{1} X_{1}+\beta_{2} X_{2}+\beta_{3} X_{3}+\beta_{4} X_{4}+\beta_{5} X_{5}+\beta_{6} X_{6}+ \\
& \beta_{7} X_{7}+\beta_{8} X_{8}+\beta_{9} X_{9}+b_{10} X_{10}+E \\
Y= & \text { peubah tidak bebas (ketahanan pangan } \\
& \text { yang diukur berdasarkan Tingkat Kecu- } \\
& \text { kupan Energi) } \\
\beta= & \text { koefisien regresi } \\
X_{1}= & \text { peubah bebas pertama (penguasaan lahan) } \\
X_{2}= & \text { peubah bebas kedua (modal kerja) } \\
X_{3}= & \text { peubah bebas ketiga (kerjasama) } \\
X_{4}= & \text { peubah bebas keempat (pendidikan formal } \\
& \text { kepala keluarga) } \\
X_{5}= & \text { peubah bebas kelima (pendidikan non } \\
& \text { formal kepala keluarga) } \\
X_{6}= & \text { peubah bebas keenam (tujuan penerapan } \\
& \text { pertanian organik) } \\
X_{7}= & \text { peubah bebas ketujuh (pengelolaan } \\
& \text { limbah) } \\
X_{8}= & \text { peubah bebas kedelapan (pengetahuan } \\
& \text { bertani secara organik) } \\
X_{9}= & \text { peubah bebas kesembilan (produktivitas } \\
& \text { beras organik) } \\
X_{10}= & \text { peubah bebas kesepuluh (pendapatan) } \\
\mathrm{E}= & \text { galat }
\end{aligned}
$$

Luas penguasaan lahan untuk memenuhi kebutuhan hidup minimal merupakan penguasaan lahan oleh rumah tangga petani yang luasnya mencukupi untuk memenuhi kebutuhan hidup minimal. Pada kenyataannya kebutuhan hidup manusia tidak hanya makan sehingga kebutuhan hidup minimal di sini sudah termasuk kebutuhan hidup lainnya. Untuk menghitung luas lahan yang diperlukan guna memenuhi kebutuhan hidup minimal tersebut diasumsikan bahwa seluruh hasil panen beras organik digunakan untuk memenuhi kebutuhan hidup minimal, yaitu sebesar Rp 10000 per orang per hari.
Luas penguasaan lahan untuk memenuhi rata-rata kecukupan energi merupakan penguasaan lahan oleh rumah tangga petani yang luasnya mencukupi untuk memenuhi kebutuhan rata-rata kecukupan energi penduduk Indonesia sebesar $2000 \mathrm{kkal}$. Dengan memperhitungkan rata-rata tingkat produksi, maka dapat ditentukan luas lahan yang dibutuhkan untuk memenuhi kebutuhan rata-rata kecukupan energi tersebut.

Luas lahan $/$ keluarga $=$ Kons. Beras Rumahtangga

Produksivitas Beras / Rumah

\section{HASIL DAN PEMBAHASAN}

\section{Karakteristik Rumahtangga Contoh}

Data mengenai karakteriktik contoh penelitian ini disajikan pada Tabel 1 seperti berikut:

Tabel 1. Karakteristik Rumahtangga Contoh

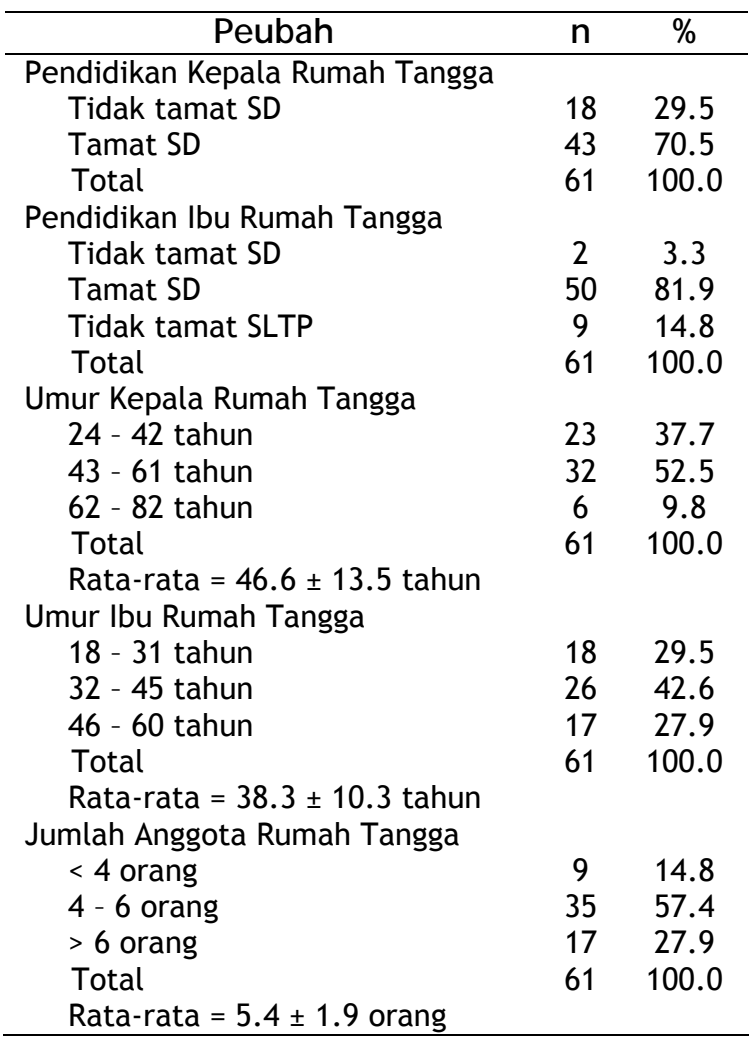

Tingkat pendidikan kepala rumah tangga lebih rendah daripada ibu rumah tangga. Sebagian besar ibu rumah tangga $(96.7 \%)$ telah berhasil menamatkan sekolah dasarnya, bahkan $14.8 \%$ diantaranya berhasil melanjutkan ke SLTP walaupun tidak sampai tamat. Walaupun orang tuanya berpendidikan rendah, namun tidak ada di antara anak-anak mereka yang 
tidak bersekolah. Sampai dengan penelitian ini dilakukan, pendidikan tertinggi anak-anak baru sampai SLTA, belum ada yang mencapai akademi atau perguruan tinggi.

Rata-rata umur kepala rumah tangga $46.6 \pm 13.5$ tahun dengan selang $24-82$ tahun. Rata-rata umur ibu rumah tangga $38.3 \pm 10.3$ tahun dengan selang 18 - 60 tahun. Sedangkan jumlah anggota rumah tangga $5.4 \pm 1.9$ orang dengan selang 2 - 12 orang.

\section{Tingkat Ketahanan Pangan Rumahtangga}

Rata-rata luas lahan yang dikuasai petani yaitu $0.244 \pm 0.106$ ha. Tabel 2 menunjukkan bahwa berdasarkan luas lahan yang dikuasai, maka rumah tangga petani tegolong petani gurem karena sebagian besar $(96.7 \%)$ hanya menguasai lahan $<0.5$ ha. Hal ini terjadi karena petani yang melakukan usahatani padi organik ini memang berasal dari petani miskin, yang bekerja sebagai buruh tani.

Tabel 2. Sebaran Rumahtangga menurut Kategori Peubah yang Menentukan Ketahanan Pangan

\begin{tabular}{|c|c|c|}
\hline Peubah & $\mathbf{n}$ & $\%$ \\
\hline \multicolumn{3}{|l|}{ Penguasaan lahan } \\
\hline Gurem (< 0.5 ha, dengan rasio luas/anggota rumah tangga $0.014-0.125)$ & 59 & 96.7 \\
\hline Menengah $(0.5-0.9 \mathrm{ha}$, dengan rasio luas/anggota rumah tangga $0.125-0.175)$ & 2 & 3.3 \\
\hline Total & 61 & 100.0 \\
\hline \multicolumn{3}{|l|}{ Modal kerja } \\
\hline Rendah (Rp 6003000 - Rp 7975 066) & 44 & 72.1 \\
\hline Sedang (Rp 7975067 - Rp 9948332 ) & 9 & 14.8 \\
\hline Tinggi (Rp 9948333 - Rp 11921000 ) & 8 & 13.1 \\
\hline Total & 61 & 100.0 \\
\hline \multicolumn{3}{|l|}{ Kerjasama } \\
\hline Pasif (nilai 1) & 7 & 11.5 \\
\hline Agak aktif (nilai 2) & 35 & 57.4 \\
\hline Aktif (nilai 3) & 19 & 31.1 \\
\hline Total & 61 & 100.0 \\
\hline \multicolumn{3}{|l|}{ Pendidikan formal kepala keluarga } \\
\hline Tidak sekolah & 23 & 37.7 \\
\hline SD & 38 & 62.3 \\
\hline Total & 61 & 100.0 \\
\hline \multicolumn{3}{|l|}{ Pendidikan non formal kepala keluarga } \\
\hline Tidak pernah (nilai 1) & 9 & 14.8 \\
\hline Pernah sedang (nilai 2) & 36 & 59.0 \\
\hline Pernah baik (nilai 3) & 16 & 26.2 \\
\hline Total & 61 & 100.0 \\
\hline \multicolumn{3}{|l|}{ Tujuan penerapan pertanian organik } \\
\hline Tidak berkelanjutan (nilai 3.0 - 4.9) & 6 & 9.8 \\
\hline Kurang berkelanjutan (nilai $5.0-6.9$ ) & 31 & 39.3 \\
\hline Berkelanjutan (nilai 7.0 - 9.0) & 24 & 50.9 \\
\hline Total & 61 & 100.0 \\
\hline \multicolumn{3}{|l|}{ Pengelolaan limbah } \\
\hline Kurang menyokong pertanian organik (nilai $3.0-4.9$ ) & 7 & 11.5 \\
\hline Menyokong pertanian organik (nilai $5.0-6.9$ ) & 37 & 60.7 \\
\hline Sangat menyokong pertanian organik (nilai $7.0-9.0$ ) & 17 & 27.9 \\
\hline Total & 61 & 100.0 \\
\hline \multicolumn{3}{|l|}{ Pengetahuan bertani secara organik } \\
\hline Rendah (nilai < 60) & 9 & 14.8 \\
\hline Sedang (nilai $60-80$ ) & 32 & 52.5 \\
\hline Tinggi (nilai > 80) & 20 & 32.8 \\
\hline Total & 61 & 100.0 \\
\hline \multicolumn{3}{|l|}{ Produktivitas beras organik } \\
\hline Rendah (30.00-49.62 ku/ha/th) & 8 & 9.8 \\
\hline Sedang (49.63 - $69.25 \mathrm{ku} / \mathrm{ha} / \mathrm{th})$ & 6 & 9.8 \\
\hline Tinggi $(69.26-88.89 \mathrm{ku} / \mathrm{ha} / \mathrm{th})$ & 49 & 80.3 \\
\hline Total & 61 & 100.0 \\
\hline \multicolumn{3}{|l|}{ Pendapatan } \\
\hline Miskin (< Rp 300 000/kapita/bulan) & 9 & 14.8 \\
\hline Tidak miskin ( $\geq$ Rp 300 000/kapita/bulan) & 52 & 85.2 \\
\hline Total & 61 & 100.0 \\
\hline \multicolumn{3}{|l|}{ Tingkat Kecukupan Energi (TKE) } \\
\hline$<70 \% \quad$ (tidak tahan pangan) & 9 & 14.8 \\
\hline $70-90 \%$ (tahan pangan) & 17 & 27.9 \\
\hline$>90 \% \quad$ (tahan pangan) & 35 & 57.4 \\
\hline Total & 61 & 100.0 \\
\hline
\end{tabular}


Untuk mendukung berlangsungnya usaha tani diperlukan modal kerja. Dalam hal ini, rata-rata modal kerja yang dimiliki petani sekitar Rp $7454000 \pm 1750000$. Dari sejumlah modal kerja yang dimiliki petani, sebesar Rp 5199000 merupakan subsidi yang diberikan oleh Lembaga Pertanian Sehat (LPS). Berdasarkan distribusinya maka sebagian besar petani (72.1\%) termasuk bermodal kerja rendah. Hal ini terjadi karena modal kerja yang dimiliki petani di luar subsidi hanyalah tenaga kerja.

Dalam hal kerjasama, sebagian besar petani $(57,4 \%)$ tergolong agak aktif. Artinya petani tersebut melakukan kerjasama dengan dua mitra kerja sama. Karena LPS dalam menjalankan programnya, selain melakukan monitoring juga melakukan pendampingan, maka salah satu mitra kerjasama tersebut adalah LPS. Mitra kerjasama yang lain adalah sesama petani. Hal ini pasti terjadi karena para petani tersebut tergabung dalam kelompok-kelompok tani yang kemudian dikoordinasikan oleh gabungan kelompok tani (gapoktan) yang bernama Silih Asih. Gapoktan ini sangat aktif dalam membina anggotanya.

Kualitas sumberdaya manusia pada rumahtangga petani diukur dari tingkat pendidikan formal dan non formal kepala keluarga. Temuan yang diperoleh dalam penelitian ini menunjukkan bahwa tingkat pendidikan petani, baik formal maupun non formal termasuk rendah. Gambaran tersebut terlihat dari tidak adanya petani yang berhasil menyelesaikan pendidikan lebih tinggi dari sekolah dasar. Sebagian besar petani (62.3\%) hanya berhasil menyelesaikan pendidikan sekolah dasar, bahkan $37.7 \%$ tidak pernah mengenyam bangku sekolah. Dalam satu tahun terakhir, sebagian besar petani (59.0\%) hanya mengikuti satu kali pendidikan non formal.

Peranan tokoh informal, dalam hal ini Ketua Gapoktan Silih Asih sangat menonjol dalam mengubah persepsi petani di lokasi penelitian tentang cara bertani. Sebagai seorang inovator, ia mencoba menerapkan cara bertani secara organik sejak tahun 2002. Karena itu, sebagian besar petani $(50.9 \%)$ telah memahami dengan baik bahwa penerapan pertanian organik adalah demi pelestarian sumberdaya alam (pertanian yang berkelanjutan). Petani telah melihat kenyataannya bahwa lahan pertanian yang tadinya sulit ditemukan cacing tanah, kini mudah mendapatkannya.

Dalam mengelola limbah, $88.6 \%$ termasuk menyokong berlangsungnya pertanian organik $(60.7 \%$ menyokong dan $27.9 \%$ sangat menyokong). Petani mengelola dan mengolah de- ngan baik limbah yang tersedia baik limbah dari sisa tanaman, kotoran ternak, maupun limbah rumah tangga. Dilihat dari sumber limbah yang dijadikan pupuk organik, sebagian besar $(45.8 \%)$ berasal dari sisa-sisa tanaman, $39.3 \%$ berasal dari kotoran hewan, dan sebagian kecil (14.9\%) berasal dari sampah rumahtangga. Kecilnya proporsi limbah yang bersumber dari sampah rumah tangga menunjukkan bahwa petani belum terbiasa menggunakan sampah rumah tangga sebagai bahan baku pupuk organik. Mereka masih memperlakukan sampah rumah tangga dengan dibakar.

Penguasaan petani dalam bertani secara organik, setengahnya $(52.5 \%)$ tergolong kategori sedang (rata-rata memperoleh nilai $76.7 \pm$ 9.0). Tingkat pendidikan formal dan non formal petani ikut berperan untuk menguasai pengetahuan seperti ini. Mengingat tingkat pendidikan formal dan non formal yang kurang menyebabkan sebagian petani $(14.8 \%)$ masih berpengetahuan rendah tentang bertani secara organik.

Produktivitas beras organik yang termasuk kategori tinggi memiliki proporsi terbesar, yaitu $80.3 \%$. Adapun rata-rata produktivitas beras per ha per tahun $73.29 \pm 12.56 \mathrm{ku}$ atau setara dengan padi kering giling $117.26 \pm 20.09$ ku. Produktivitas ini lebih besar daripada ratarata produktivitas padi sawah non organik di Kabupaten Bogor sebesar 105.62 ku per ha per tahun (BPS Jawa Barat, 2005).

Data pada Tabel 2 menunjukkan bahwa sebagian besar (85.2\%) rumahtangga petani tergolong tidak miskin, dengan rata-rata pendapatan per kapita per bulan besarnya sekitar Rp $462500 \pm 161000$ atau Rp $15500 \pm 5500$ per kapita per hari. Pendapatan ini lebih besar daripada batas yang diberikan Bank Dunia, yaitu US\$ 1 atau Rp 10000 per kapita per hari agar orang tidak disebut miskin (dengan asumsi 1 dolar AS = Rp 10 000). Walaupun demikian, pendapatan tersebut belum menggambarkan kondisi perekonomian rumah tangga yang sesungguhnya. Pada kehidupan nyata sehari-hari, petani masih harus terbebani oleh beberapa bentuk pengeluaran, seperti sandang, papan, kesehatan, dan pendidikan anak-anak. Selain itu, ketika petani tidak lagi mendapat subsidi modal kerja dari LPS, maka petani harus menyediakan biaya produksi sendiri. Biaya produksi tersebut diambil dari pendapatan.

Dilihat dari konsumsi energi, rumahtangga petani hanya mengkonsumsi energi ratarata per kapita per hari hanya sebesar 1759 Kal dengan tingkat kecukupan energi (TKE) $87.2 \%$. Dengan menggunakaan pengelompokan 
status konsumsi rumah tangga seperti yang diberikan oleh Departemen Kesehatan (seperti dikutip Sumarwan \& Sukandar, 1998), maka Tabel 4 menunjukkan bahwa sebagian besar (57.4\%) rumahtangga petani memiliki status konsumsi yang normal, atau berada pada selang 90 - 119\% AKG.

Berdasarkan tingkat kecukupan konsumsi energi dapat ditampilkan situasi ketahanan pangan rumahtangga petani. Sebagian besar rumahtangga petani (85.2\%) teridentifikasi sebagai tahan pangan dan yang tidak tahan pangan sebesar $14.8 \%$. Dengan masih adanya rumahtangga petani yang tidak tahan pangan, menunjukkan bahwa terdapat faktor-faktor yang mempengaruhinya. Padahal, semua rumahtangga petani peserta Program Pemberdayaan Petani Sehat diperlakukan sama oleh Lembaga Pertanian Sehat dalam memproduksi beras organik. Untuk mengetahui faktor-faktor (peubah bebas) yang mempengaruhi ketahanan pangan rumah tangga maka dilakukan analisis korelasi/ketergantungan dan regresi terhadap peubah-peubah yang diduga berpengaruh terhadap ketahanan pangan rumah tangga petani.

Hasil uji regresi linear berganda yang disajikan pada Tabel 3 menunjukkan bahwa secara signifikan $(p<0.0001)$ terdapat pengaruh dari peubah bebas (penguasaan lahan, modal kerja, kerjasama, pendidikan formal kepala keluarga, pendidikan non formal kepala keluarga, tujuan penerapan pertanian organik, pengelolaan limbah, pengetahuan bertani secara organik, produktivitas beras organik, dan pendapatan) dengan nilai $\mathrm{R}^{2}$ sebesar 0.9597 . Nilai $\mathrm{R}^{2}$ ini menunjukkan koefisien determinasi sehingga $95.97 \%$ kondisi ketahanan pangan rumahtangga petani penghasil beras organik dapat dijelaskan oleh kesepuluh peubah bebas tersebut. Sisanya (4.03\%) dijelaskan oleh berbagai sebab lain yang tidak dimasukkan dalam model seperti harga pangan, kebijakan pemerintah dalam hal pertanian, lingkungan, pola asuh, kesehatan/sanitasi, maupun pengetahuan gizi.

Hasil Backward Elimination dari SAS untuk memperoleh variabel bebas yang berpengaruh nyata diperoleh enam variabel yaitu penguasaan lahan, tujuan penerapan pertanian organik, pengelolaan limbah, pengetahuan bertani secara organik, produktivitas beras organik, dan pendapatan (Tabel 4). Dengan demikian untuk memprediksi (meramalkan) kondisi ketahanan pangan rumah tangga petani penghasil beras organik dapat digunakan keenam peubah bebas tersebut. Model regresi ketahanan pangan rumahtangga penghasil beras organik adalah sebagai berikut:

$$
\begin{aligned}
Y= & 46.870+2.74 E-05 X_{1}+0.146 X_{2}+0.103 X_{3}+ \\
& 1.963 X_{4}+5.794 X_{5}+2.173 X_{6}
\end{aligned}
$$

Tabel 3. Hasil Uji Regresi Linear Berganda dan Korelasi antara Peubah Bebas dan Tidak Bebas

\begin{tabular}{lrrrr}
\hline \multirow{2}{*}{ Peubah } & \multicolumn{2}{c}{ Regresi } & \multicolumn{2}{c}{ Korelasi } \\
\cline { 2 - 5 } & \multicolumn{1}{c}{$\boldsymbol{P}$} & $\mathbf{P r}>\mathbf{F}$ & $\mathbf{r}$ & Pr $>$ F \\
\hline Intercept & 45.834 & $<0.0001$ & & \\
Penguasaan lahan & 5.637 & 0.0482 & 0.395 & 0.002 \\
Modal kerja & $1.438 \mathrm{E}-07$ & 0.3563 & 0.065 & 0.620 \\
Kerjasama & 0.116 & 0.9205 & 0.811 & 0.000 \\
$\begin{array}{l}\text { Pendidikan formal } \\
\text { kepala keluarga }\end{array}$ & -0.163 & 0.7843 & -0.064 & 0.622 \\
$\begin{array}{l}\text { Pendidikan non formal } \\
\text { kepala keluarga }\end{array}$ & 0.546 & 0.4405 & 0.656 & 0.000 \\
$\begin{array}{l}\text { Tujuan penerapan } \\
\text { pertanian organik }\end{array}$ & 1.870 & 0.0272 & 0.866 & 0.000 \\
$\begin{array}{l}\text { Pengelolaan limbah } \\
\text { Pengetahuan bertani } \\
\text { secara organik }\end{array}$ & 1.641 & 0.1800 & 0.815 & 0.000 \\
$\begin{array}{l}\text { Produktivitas beras } \\
\text { organik }\end{array}$ & 0.152 & 0.0080 & 0.866 & 0.000 \\
Pendapatan & 0.099 & 0.0021 & 0.705 & 0.000 \\
\hline R $^{2}=0.9597$ & $2.759 \mathrm{E}-05$ & $<0.0001$ & 0.954 & 0.000 \\
\hline
\end{tabular}

Tabel 4. Hasil Uji Regresi Linear Berganda untuk Peubah Berpengaruh Nyata

\begin{tabular}{clccc}
\hline Kode & \multicolumn{1}{c}{ Peubah } & $\begin{array}{c}\text { Parameter } \\
\text { Estimate }\end{array}$ & $\begin{array}{c}\mathbf{R}^{2} \\
\text { Parsial }\end{array}$ & Peluang \\
\hline $\mathrm{X}_{1}$ & $\begin{array}{l}\text { Intercept } \\
\text { Pendapatan }\end{array}$ & $\begin{array}{c}46.870 \\
2.74 \mathrm{E}-05\end{array}$ & 0.4674 & $<0.0001$ \\
$\mathrm{X}_{2}$ & $\begin{array}{l}\text { Pengetahuan bertani } \\
\text { secara organik }\end{array}$ & 0.146 & 0.1271 & 0.0079 \\
$\mathrm{X}_{3}$ & $\begin{array}{l}\text { Produktivitas beras } \\
\text { organik }\end{array}$ & 0.103 & 0.1013 & 0.0009 \\
$\mathrm{X}_{4}$ & $\begin{array}{l}\text { Tujuan penerapan } \\
\text { pertanian organik }\end{array}$ & 1.963 & 0.1141 & 0.0125 \\
$\mathrm{X}_{5}$ & $\begin{array}{l}\text { Penguasaan lahan } \\
\mathrm{X}_{6}\end{array}$ & 5.794 & 0.0270 & 0.0357 \\
\hline
\end{tabular}

Dari Tabel 4 terlihat bahwa $\mathrm{R}^{2}$ parsial untuk peubah pendapatan merupakan yang terbesar. Hal ini menunjukkan bahwa di antara enam peubah yang berpengaruh nyata, peubah pendapatan merupakan peubah yang paling menentukan. $\mathrm{R}^{2}$ parsial untuk peubah pendapatan sebesar 0.4674 menunjukkan bahwa 46.74\% kondisi ketahanan pangan rumahtangga petani penghasil beras organik dapat dijelaskan oleh peubah pendapatan. Hasil penelitian menunjukkan bahwa pendapatan sebagai salah satu faktor determinan dari ketahanan pangan memberikan hasil uji regresi yang positif nyata $(p<0.05)$. Hal ini menunjukkan bahwa ketahanan pangan dipengaruhi secara nyata oleh pendapatan. Hasil uji korelasi Pearson juga menunjukkan adanya derajat keeratan hubungan yang positif sangat nyata $(p<0.01$; $r$ $=0.954$ ). Rumahtangga tidak tahan pangan, ra- 
ta-rata pendapatannya hanya sekitar Rp 4500 \pm 200 per kapita per hari, lebih rendah daripada batas Bank Dunia. Penyebabnya adalah luas lahan yang dimiliki keluarga tidak tahan pangan lebih kecil, yaitu $48.5 \%$ luas lahan keluarga tahan pangan. Hal ini akan menurunkan pendapatan yang diperoleh dari hasil penjualan beras organik bagi keluarga tidak tahan pangan. Hal ini juga terlihat dari rata-rata $B / C$ ratio untuk keluarga tidak tahan pangan sebesar 1.07 (Tabel 5); yang menunjukkan bahwa hasil penjualan penjualan beras organik hampir sama dengan biaya yang dikeluarkan untuk memproduksinya. Sementara rata-rata B/C ratio untuk keluarga tahan pangan sebesar 1.63 (Tabel 6) dan rata-rata $B / C$ ratio untuk keseluruhan 1.54 (Tabel 4).

Hasil uji regresi menunjukkan bahwa ketahanan pangan dipengaruhi positif sangat nyata $(p<0.01$ ) oleh pengetahuan bertani secara organik. Hal ini menunjukkan bahwa dengan penguasaan bertani secara organik yang semakin baik akan meningkatkan ketahanan pangan. Demikian halnya dengan uji korelasi Pearson antara ketahanan pangan dengan pengetahuan bertani secara organik yang menun- jukkan derajat keeratan hubungan yang positif sangat nyata $(p<0.01 ; r=0.866)$. Jika dianalisis berdasarkan uji korelasi Pearson antara pengetahuan bertani secara organik dengan produktivitas beras organik, diperoleh hasil positif yang sangat nyata ( $<<0.01 ; r=0,674)$. Hal ini menunjukkan bahwa terdapat derajat keeratan hubungan yang nyata antara pengetahuan bertani secara organik dengan produktivitas beras organik. Artinya, semakin petani menguasai pengetahuan untuk bertani organik, produktivitasnya akan semakin meningkat.

Hasil uji regresi menunjukkan adanya pengaruh produktivitas beras organik terhadap ketahanan pangan yang positif sangat nyata $(p<0.01)$. Uji korelasi Pearson menunjukkan adanya derajat keeratan hubungan antara produksi beras organik dengan ketahanan pangan yang positif sangat nyata ( $p<0.01 ; r=0.705)$. Hal ini menunjukkan bahwa semakin meningkat produksi beras organik, semakin meningkat pula ketahanan rumah tangga tersebut. Ratarata produktivitas beras organik akan menjadi lebih besar apabila yang dihitung hanya produksi rumah tangga yang tahan pangan saja, yaitu $77.55 \pm 6.80 \mathrm{ku} / \mathrm{ha} / \mathrm{tahun}$.

Tabel 5. Keragaan Rumahtangga Petani berdasarkan Peubah yang Berpengaruh Nyata

\begin{tabular}{lcccc}
\hline \multicolumn{1}{c}{ Peubah } & Rata-rata & SD & Min & Max \\
\hline Pendapatan (Rp/kapita/bulan) & 462374 & 160843 & 127600 & 660675 \\
- Biaya operasional bertani beras organik & 7453656 & 1749247 & 6003000 & 11921000 \\
(Rp/ha/musim tanam) & & & & \\
- Hasil penjualan beras organik & 10992861 & 1883810 & 4500000 & 13333500 \\
(Rp/ha/musim tanam) & 1.54 & 0.40 & 0.51 & 2.20 \\
- B/C ratio & 76.74 & 9.04 & 59.00 & 89.00 \\
Pengetahuan bertani secara organik (nilai) & 73.29 & 12.56 & 30.00 & 88.89 \\
Produktivitas beras organik (ku/ha/th) & 18.25 & 8.75 & 4.50 & 40.00 \\
- Produksi beras organik (ku/th) & 2.30 & 0.64 & 1.00 & 3.00 \\
Tujuan penerapan pertanian organik (nilai) & 0.244 & 0.106 & 0.125 & 0.525 \\
Penguasaan lahan (ha) & 2.16 & 0.61 & 1.00 & 3.00 \\
Pengelolaan limbah (nilai) & & & & \\
\hline
\end{tabular}

Tabel 6. Keragaan Rumahtangga Petani Tidak Tahan Pangan berdasarkan Peubah yang berpengaruh nyata

\begin{tabular}{lcccc}
\hline \multicolumn{1}{c}{ Peubah } & \multicolumn{4}{c}{ Tidak tahan pangan } \\
\cline { 2 - 5 } & Rata-rata & SD & Min & Max \\
\hline Pendapatan (Rp/kapita/bulan) & 133905 & 6424 & 127600 & 147111 \\
- Biaya operasional bertani beras organik (Rp/ha/musim tanam) & 7251222 & 19823106.003 .000 & 11779000 \\
- Hasil penjualan beras organik (Rp/ha/musim tanam) & 7300000 & 14071254500000 & 9600000 \\
- B/C ratio & 1.07 & 0.32 & 0.51 & 1.60 \\
Pengetahuan bertani secara organik (nilai) & 59.00 & 0.00 & 59.00 & 59.00 \\
Produktivitas beras organik (ku/ha/th) & 48.67 & 9.38 & 30.00 & 64.00 \\
- Produksi beras organik (ku/th) & 6.17 & 1.00 & 4.50 & 8.00 \\
Tujuan penerapan pertanian organik (nilai) & 1.33 & 0.50 & 1.00 & 2.00 \\
Penguasaan lahan (ha) & 0.128 & 0.008 & 0.125 & 0.150 \\
Pengelolaan limbah (nilai) & 1.22 & 0.44 & 1.00 & 2.00 \\
\hline
\end{tabular}


Hasil uji regresi mengindikasikan bahwa ketahanan pangan dipengaruhi secara positif nyata $(p<0,05)$ oleh peubah bebas tujuan penerapan pertanian organik. Hasil uji korelasi Spearman juga menunjukkan adanya derajat keeratan hubungan yang positif sangat nyata $(p<0.01 ; r=0.866)$ antara ketahanan pangan dengan peubah tujuan penerapan ketentuanketentuan dalam pertanian organik.

Hasil uji regresi terhadap penguasaan lahan memberikan hasil yang positif nyata $(p<$ 0.05), yang menunjukkan bahwa ketahanan pangan dipengaruhi oleh peubah penguasaan lahan. Uji korelasi Pearson menunjukkan bahwa antara ketahanan pangan dan peubah penguasaan lahan memiliki derajat keeratan hubungan yang positif sangat nyata $(p<0.01, r=$ $0.395)$. Rumahtangga tak tahan pangan menguasai lahan (rata-rata $0.128 \pm 0.008$ ha) lebih kecil daripada rumah tangga tahan pangan ( $\mathrm{ra}$ ta-rata $0.264 \pm 0.102 \mathrm{ha}$ ).

Hasil uji korelasi Spearman menunjukkan adanya hubungan yang positif sangat nyata antara pengelolaan limbah dengan ketahanan pangan $(p<0.01 ; r=0.815)$, merupakan hal yang wajar. Penyebabnya adalah petani harus mengelola limbah untuk dijadikan pupuk organik.
Semua petani melakukan pengelolaan limbah baik limbah dari sisa tanaman, kotoran ternak, maupun limbah rumah tangga.

\section{Luas Penguasaan Lahan untuk Memenuhi Kebutuhan Hidup Minimal}

Luas penguasaan lahan untuk memenuhi kebutuhan hidup minimal diartikan sebagai penguasaan lahan oleh rumah tangga petani yang luasnya mencukupi untuk memenuhi kebutuhan hidup minimal. Oleh karena pada kenyataannya kebutuhan hidup manusia tidak hanya makan maka kebutuhan hidup minimal di sini sudah termasuk kebutuhan hidup lainnya. Untuk menghitung luas lahan yang diperlukan guna memenuhi kebutuhan hidup minimal tersebut diasumsikan bahwa seluruh hasil panen beras organik digunakan untuk memenuhi kebutuhan hidup minimal, yaitu sebesar Rp 10000 per orang per hari.

Dengan harga jual beras organik sebesar Rp 3000 per kg maka tiap anggota rumahtangga harus memiliki beras sebanyak $3333 \mathrm{~g}$ tiap hari atau sekitar $12.17 \mathrm{ku} / \mathrm{kapita} / \mathrm{tahun}$. De ngan rata-rata produktivitas sebesar $73.29 \mathrm{ku} /$ ha/tahun seperti yang disajikan pada Tabel 8,

Tabel 7. Keragaan Rumahtangga Petani Tahan Pangan berdasarkan Peubah yang Berpengaruh Nyata

\begin{tabular}{lcccc}
\hline \multicolumn{1}{c}{ Peubah } & \multicolumn{4}{c}{ Tahan pangan } \\
\cline { 2 - 5 } & Rata-rata & SD & Min & Max \\
\hline Pendapatan (Rp/kapita/bulan) & 519225 & 89968 & 316917 & 660675 \\
- Biaya operasional bertani beras organik & 7488692 & 1724806 & 6003000 & 11921000 \\
$\quad$ (Rp/ha/musim tanam) & & & & \\
- Hasil penjualan beras organik (Rp/ha/musim & 11632010 & 1020447 & 6922500 & 13333500 \\
$\quad$ tanam) & 1.63 & 0.36 & 0.79 & 2.20 \\
- B/C ratio & 79.81 & 5.58 & 70.00 & 89.00 \\
Pengetahuan bertani secara organik (nilai) & 77.55 & 6.80 & 46.15 & 88.89 \\
Produktivitas beras organik (ku/ha/th) & 20.35 & 7.73 & 10.00 & 40.00 \\
- Produksi beras organik (ku/th) & 2.46 & 0.50 & 2.00 & 3.00 \\
Tujuan penerapan pertanian organik (nilai) & 0.264 & 0.102 & 0.125 & 0.525 \\
Penguasaan lahan (ha) & 2.33 & 0.47 & 2.00 & 3.00 \\
Pengelolaan limbah (nilai) & & & & \\
\hline
\end{tabular}

Tabel 8 Keragaan Unsur-unsur Penentu Luas Lahan untuk Memenuhi Kebutuhan Hidup Minimal

\begin{tabular}{lcccc}
\hline \multicolumn{1}{c}{ Unsur-unsur } & \multicolumn{4}{c}{ Ideal } \\
\cline { 2 - 5 } & Rata-rata & SD & Min & Max \\
\hline Produksi beras rumah tangga (ku/tahun) & 18.25 & 8.75 & 4.50 & 40.00 \\
Produktivitas beras rumah tangga (ku/ha/tahun) & 73.29 & 12.56 & 30.00 & 88.89 \\
Jumlah anggota keluarga (orang) & 5.4 & 1.9 & 2.0 & 12.0 \\
Penguasaan lahan per kapita (m²) & 1735 & 459 & 1369 & 4057 \\
Penguasaan lahan per rumah tangga $\left(\mathrm{m}^{2}\right)$ & 9492 & 4306 & 3423 & 20285 \\
\hline
\end{tabular}


Tabel 9. Luas Lahan (ha) yang Diperlukan Keluarga untuk Dapat Memenuhi Kebutuhan Hidup Minimal menurut Jumlah Anggota Rumahtangga

\begin{tabular}{ccc}
\hline $\begin{array}{c}\text { Klasifikasi J umlah Anggota } \\
\text { Rumahtangga }\end{array}$ & $\begin{array}{c}\text { Jumlah Anggota } \\
\text { Rumahtangga (n) }\end{array}$ & $\begin{array}{c}\text { Luas lahan yang diperlukan } \\
\text { dengan rumus n x 0,17 ha }\end{array}$ \\
\hline Kecil & 2 & 0.34 \\
$2-3$ & 3 & 0.51 \\
\hline Sedang & 4 & 0.68 \\
$4-5$ & 5 & 0.85 \\
\hline & 6 & 1.02 \\
Besar & 7 & 1.19 \\
$6-12$ & 8 & 1.36 \\
& 9 & 1.53 \\
& 10 & 1.70 \\
& 11 & 1.87 \\
\hline
\end{tabular}

maka setiap anggota keluarga harus menguasai lahan seluas $1735 \pm 459 \mathrm{~m}$ persegi dengan kisaran 1369 - $4057 \mathrm{~m}$ persegi. Dengan memperhitungkan jumlah anggota rumahtangga, maka untuk memenuhi kebutuhan hidup minimal, tiap rumah tangga hendaknya menguasai lahan seluas $9492 \pm 4306 \mathrm{~m}$ persegi atau $0.95 \pm 0.43$ ha dengan kisaran $0.34-2.02$ ha. Pada Tabel 9 disajikan rincian luas lahan yang diperlukan untuk memenuhi kebutuhan hidup minimal menurut jumlah anggota rumah tangga.

Bantuan subsidi lahan yang berasal dari Lembaga Pertanian Sehat yang diterima petani dengan luas penguasaan lahan hanya $1125 \mathrm{~m}^{2}$ atau 0.11 ha per rumah tangga sementara yang dibutuhkan rata-rata 0.95 ha per rumahtangga. Karena itu, jika dikaitkan dengan kebutuhan hidup manusia seutuhnya, mulai dari pangan, sandang, dan papan, sekali pun pada taraf minimal (dengan asumsi Rp 10000 per kapita per hari) maka luas lahan subsidi tersebut belum memadai.

\section{Luas Penguasaan Lahan untuk Memenuhi} Kebutuhan Rata-rata Kecukupan Energi

Luas penguasaan lahan untuk memenuhi kebutuhan rata-rata kecukupan energi diarti- kan sebagai penguasaan lahan oleh rumahtangga petani yang luasnya mencukupi untuk memproduksi beras guna memenuhi rata-rata kecukupan energi penduduk Indonesia, yaitu sebesar 2000 kkal.

Jika kebutuhan energi diasumsikan hanya dari beras, maka untuk memenuhi ratarata kecukupan energi sebesar 2000 kkal setiap anggota rumah tangga, dibutuhkan beras sebanyak $611 \mathrm{~g}$ setiap hari atau sekitar $2.23 \mathrm{ku}$ /kapita/tahun. Tabel 10 menunjukkan bahwa rata-rata produktivitas sebesar $73.29 \mathrm{ku} / \mathrm{ha} /$ tahun. Dengan demikian, tiap anggota keluarga harus menguasai lahan seluas $318 \pm 84 \mathrm{~m}^{2}$ dengan kisaran $251-744 \mathrm{~m}^{2}$. Dengan memperhitungkan jumlah anggota rumahtangga, maka untuk memenuhi kebutuhan rata-rata kecukupan energi, tiap rumahtangga hendaknya menguasai lahan seluas $1.740 \pm 789 \mathrm{~m}^{2}$ dengan kisaran $627-3718 \mathrm{~m}^{2}$. Karena itu, bantuan subsidi dari Lembaga Pertanian Sehat dengan luas penguasaan lahan $1125 \mathrm{~m}^{2}$ belum mencukupi untuk memenuhi kebutuhan energi rata-rata. Pada Tabel 11 disajikan rincian luas lahan yang diperlukan untuk memenuhi rata-rata kecukupan energi menurut jumlah anggota rumahtangga.

Tabel 10. Keragaan Unsur-unsur Penentu Luas Lahan untuk Memenuhi Rata-rata Kecukupan Energi

\begin{tabular}{lcccc}
\hline \multirow{2}{*}{ Unsur-unsur } & \multicolumn{4}{c}{ Ideal } \\
\cline { 2 - 5 } & Rata-rata & SD & Min & Max \\
\hline Produksi beras rumah tangga (ku/tahun) & 18.25 & 8.75 & 4.50 & 40.00 \\
Produktivitas beras rumah tangga (ku/ha/tahun) & 73.29 & 12.56 & 30.00 & 88.89 \\
Jumlah anggota keluarga (orang) & 5.4 & 1.9 & 2.0 & 12.0 \\
Penguasaan lahan per kapita $\left(\mathrm{m}^{2}\right)$ & 318 & 84 & 251 & 744 \\
Penguasaan lahan per rumah tangga $\left(\mathrm{m}^{2}\right)$ & 1740 & 789 & 627 & 3718 \\
\hline
\end{tabular}


Tabel 11. Luas Lahan $\left(\mathrm{m}^{2}\right)$ yang Diperlukan Keluarga untuk Dapat Memenuhi Rata-rata Kecukupan Energi Menurut Jumlah Anggota Rumahtangga

\begin{tabular}{ccc}
\hline $\begin{array}{c}\text { Klasifikasi J umlah Anggota } \\
\text { Rumahtangga }\end{array}$ & $\begin{array}{c}\text { J umlah anggota } \\
\text { Rumahtangga (n) }\end{array}$ & $\begin{array}{c}\text { Luas Lahan yang Diperlukan } \\
\text { dengan Rumus } \mathbf{~} \mathbf{3} \mathbf{3 1 8} \mathbf{~ m}^{\mathbf{2}}\end{array}$ \\
\hline Kecil & 2 & 636 \\
$2-3$ & 3 & 954 \\
\hline Sedang & 4 & 1272 \\
$4-5$ & 5 & 1590 \\
\hline & 6 & 1908 \\
Besar & 7 & 2226 \\
$6-12$ & 8 & 2544 \\
& 9 & 2862 \\
& 10 & 3180 \\
& 11 & 3498 \\
\end{tabular}

Status Luas Penguasaan Lahan Ditinjau dari Ketahanan Pangan Rumahtangga

Tabel 12 menunjukkan bahwa rumah tangga petani penghasil beras organik yang termasuk kategori tidak tahan pangan ternyata luas penguasaan lahannya memang tidak mencukupi untuk memenuhi kebutuhan pangannya. Ketidakcukupan penguasaan lahan ini terjadi baik untuk memenuhi kebutuhan hidup minimal mau pun rata-rata kecukupan energi bagi penduduk Indonesia.

Tabel 12. Keragaan Status Luas Penguasaan Lahan Rumahtangga untuk Memenuhi Kebutuhan Hidup Minimal dan RataRata Kecukupan Energi Ditinjau dari Status Ketahanan Pangan Rumahtangga

\begin{tabular}{lcccccccc}
\hline \multirow{2}{*}{$\begin{array}{c}\text { Status } \\
\text { Rumah- } \\
\text { tangga }\end{array}$} & \multicolumn{3}{c}{$\begin{array}{c}\text { Kebutuhan hidup } \\
\text { minimal }\end{array}$} & \multicolumn{4}{c}{$\begin{array}{c}\text { Rata-rata } \\
\text { kecukupan energi }\end{array}$} \\
\cline { 2 - 9 } & \multicolumn{2}{c}{ Defisit } & Surplus & Defisit & Surplus \\
\cline { 2 - 10 } & $\%$ & $\mathbf{n}$ & $\%$ & $\mathbf{n}$ & $\%$ & $\mathbf{n}$ & $\%$ & $\mathbf{n}$ \\
\hline $\begin{array}{l}\text { Tidak Tahan } \\
\text { Pangan }\end{array}$ & 100 & 9 & 0 & 0 & 100 & 9 & 0 & 0 \\
$\begin{array}{l}\text { Tahan } \\
\text { Pangan }\end{array}$ & 98.1 & 51 & 1.9 & 1 & 17.3 & 9 & 82.7 & 43 \\
\hline
\end{tabular}

Di antara rumah tangga petani penghasil beras organik yang termasuk tahan pangan, terdapat $17.3 \%$ yang luas penguasaan lahannya tidak mencukupi untuk memenuhi rata-rata kecukupan energi. Bahkan untuk memenuhi kebutuhan hidup minimal, rumahtangga yang tergolong tahan pangan pun hampir semua $(98.1 \%)$, luas penguasaan lahannya tidak mencukupi. Hal ini mengindikasikan bahwa konsumsi pangan rumahtangga tersebut sebagian diperoleh dari konversi pendapatan di luar produksi beras organik. Gambar 1 menunjukkan bahwa memang betul proporsi pendapatan terbesar kedua (13.9\%) diperoleh dari non usahatani seperti berjualan di warung atau berdagang di pasar, menjadi sopir, karyawan pabrik, dan kiriman uang oleh anggota keluarga yang bekerja di luar kota, terutama di Jakarta. Jadi walaupun nampaknya rumahtangga tersebut tahan pangan dilihat dari konsumsi pangannya, sebenarnya rumahtangga tersebut masih mengalami masalah finansial untuk memenuhi seluruh kebutuhan hidup rumahtangga yang pada kenyataanya tidak hanya pangan.

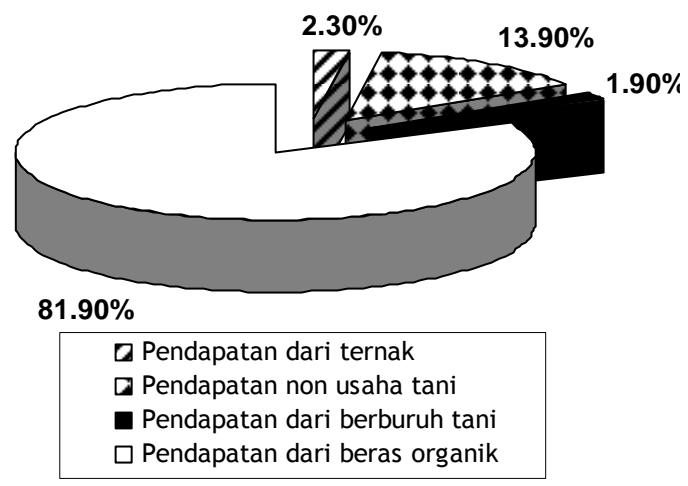

Gambar 1. Sebaran Proporsi Sumber Pendapatan terhadap Total Pendapatan

Status Luas Lahan Sawah Di Desa Ciburuy, Kecamatan Cigombong, dan Kabupaten Bogor

Untuk memenuhi kebutuhan beras berdasarkan kebutuhan hidup minimal dan ratarata kecukupan energi, Desa Ciburuy, yang menurut Data Monografi Desa tahun 2006 memiliki jumlah penduduk 9293 orang dan luas sawah 80 ha, menurut Tabel 13 mengalami defisit lahan sawah berturut-turut sebesar 1915 dan 269\%. Pada tingkat Kecamatan Cigombong yang berpenduduk 68504 orang (BPS, 2006), dengan luas lahan sawah aktual sebesar 1065 ha (Distanhut, 2007), maka untuk memenuhi kebutuhan beras berdasarkan kebutuhan hidup 
Tabel 13. Kebutuhan Lahan Sawah untuk Memenuhi Kebutuhan Hidup Minimal dan Rata-rata kecukupan energi

\begin{tabular}{|c|c|c|c|c|c|c|}
\hline \multirow{2}{*}{ Untuk pemenuhan } & \multicolumn{2}{|c|}{$\begin{array}{l}\text { Desa Ciburuy (luas } \\
\text { sawah } 80 \text { ha) }\end{array}$} & \multicolumn{2}{|c|}{$\begin{array}{c}\text { Kecamatan Cigombong (luas } \\
\text { sawah 1.065ha) }\end{array}$} & \multicolumn{2}{|c|}{$\begin{array}{l}\text { Kabupaten Bogor (luas } \\
\text { sawah 48.425 ha) }\end{array}$} \\
\hline & $\begin{array}{l}\text { Kebutuhan } \\
\text { (ha) }\end{array}$ & $\begin{array}{l}\text { Defisit } \\
(\%)\end{array}$ & $\begin{array}{l}\text { Kebutuhan } \\
\text { (ha) }\end{array}$ & Defisit (\%) & $\begin{array}{l}\text { Kebutuhan } \\
\text { (ha) }\end{array}$ & Defisit (\%) \\
\hline $\begin{array}{l}\text { Kebutuhan } \\
\text { hidup minimal }\end{array}$ & 1612 & 1915 & 11885 & 1016 & 641986 & 1226 \\
\hline $\begin{array}{l}\text { Rata-rata } \\
\text { kecukupan energi }\end{array}$ & 296 & 269 & 2178 & 105 & 117667 & 143 \\
\hline
\end{tabular}

minimal dan rata-rata kecukupan energi, berturut-turut terjadi defisit 1016 dan 105\%. Pada tingkat Kabupaten Bogor yang berpenduduk 3700207 orang dengan luas lahan sawah yang hanya 48425 ha (BPS, 2006), untuk memenuhi kebutuhan beras berdasarkan kebutuhan hidup minimal dan rata-rata kecukupan energi, berturut-turut terjadi defisit 1226 dan 143\%.

Melihat kondisi defisit penguasaan lahan tersebut, maka upaya alih fungsi lahan pertanian harus dikendalikan melalui penegakan peraturan secara lebih tegas dan penguatan status kepemilikan lahan, ada pun lahan pertanian yang tersisa ditetapkan sebagai lahan abadi. Hal ini sesuai dengan arah kebijakan pembangunan ketahanan pangan seperti yang tertuang dalam buku Kebijakan Umum Ketahanan Pangan 2006 - 2009. Dalam buku tersebut disebutkan bahwa pada sisi ketersediaan, salah satu arah kebijakan ketahanan pangan adalah meningkatkan kapasitas produksi nasional dengan menetapkan lahan abadi untuk produksi pangan. Sejalan dengan hal tersebut, salah satu tujuan ketahanan pangan adalah meningkatkan rasio lahan per orang (land-man ratio) melalui penetapan lahan abadi beririgasi dan lahan kering. Salah satu elemen kebijakan umum ketahan pangan menyebutkan bahwa untuk menjamin ketersediaan pangan dilakukan kegiatan antara lain penetapan kawasan pertanian dan pengendalian alih fungsi lahan pertanian.

\section{KESIMPULAN}

Rumah tangga petani penghasil beras organik yang termasuk tahan pangan sebesar $85.2 \%$ dan yang tidak tahan pangan $14.8 \%$. Berbagai faktor determinan yang mempengaruhi ketahanan pangan adalah pendapatan, pengetahuan bertani secara organik, produktivitas beras organik, tujuan penerapan ketentuan dalam pertanian organik, penguasaan lahan, dan pengelolaan limbah.

Agar rumah tangga petani penghasil beras organik terpenuhi kebutuhan: a. Hidup minimal maka luas penguasaan lahan tiap anggota rumah tangga sekitar $1735 \mathrm{~m}^{2}$ dan tiap rumah tangga sekitar $9492 \mathrm{~m}^{2}$.

b. Rata-rata kecukupan energi maka luas penguasaan lahan tiap anggota rumah tangga sekitar $318 \mathrm{~m}^{2}$ dan tiap rumah tangga sekitar $1740 \mathrm{~m}^{2}$.

Luas penguasaan lahan oleh rumahtangga petani penghasil beras organik yang tergolong tahan pangan, tidak mencukupi untuk memenuhi kebutuhan hidup manusia seutuhnya, mulai dari pangan, sandang, dan papan, sekali pun pada taraf minimal (dengan asumsi Rp 10000 per kapita per hari).

Luas lahan sawah baik di tingkat Desa Ciburuy, di tingkat Kecamatan Cigombong, maupun di tingkat Kabupaten Bogor tidak mencukupi untuk memenuhi kebutuhan beras.

\section{DAFTAR PUSTAKA}

Allen P \& Dusen D van. 1988. Sustainable Agriculture: Choosing the future. In Global Perspective on Agroecology and Sustainable Agricultural Systems. University of California, Santa Cruz, CA, USA.

Andoko A. 2004. Budi Daya Padi Secara Organik. Penebar Swadaya, Depok.

[BKKBN] Badan Koordinasi Keluarga Berencana Nasional. 2006. Balita Gizi Buruk di Kabupaten Bogor Meningkat 79 Persen. http://www.bkkbn.go.id./print.php?tid= 2\&rid=680. [28 November 2006].

BPS. 2004. Sensus Pertanian 2003, Angka Propinsi Jawa Barat, Hasil Pendaftaran Rumah Tangga. Badan Pusat Statistik Propinsi Jawa Barat, Bandung.

BPS. 2006. Kabupaten Bogor dalam Angka 2006. BPS, Bogor. 
[Distanhut] Dinas Pertanian dan Kehutanan. 2007. Monografi Pertanian dan Kehutanan Kabupaten Bogor Tahun 2006. Distanhut Kabupaten Bogor, Bogor.

[FAO] Food Agriculture Organization. 2002. Organic Agriculture, Environment and Food Security. FAO, The United Nations, Rome.

Mantra IB \& Kasto. 1989. Penentuan Sampel. Dalam Singarimbun M, Effendi S, (ed.), Metode Penelitian Survei. (hlm. 171), LP3ES, Jakarta.

Maxwell S \& Frankenberger TR. 1992. Household Food Security: Concepts, Indicators, Measurements, A Technical Review. International Fund for Agricultural
Development-United Nations Children's Fund, Rome.

Reijntjes C, Haverkort B, \& Waters-Bayer A. 1992. Pertanian Masa Depan, Pengantar untuk Pertanian Berkelanjutan dengan Input Luar Rendah (Sukoco Y, penerjemah). Fliert E van de, Hidayat B, Flemish Organization for Assistance in Development, editor. The Macmillan Press, London.

SNI. 2002. Sistem Pangan Organik. Badan Standarisasi Nasional. http://www.biocert. or.id/download/SNI_ORG.pdf [12 Juni 2004].

Sutanto R. 2002. Pertanian Organik Menuju Pertanian Alternatif dan Berkelanjutan. Penerbit Kanisius, Yogyakarta. 